\title{
Islamic accounting reporting and economic development: Nigerian perspective
}

\author{
Ibrahim Alkalia, Mohammed Yusuf Alkali ${ }^{b^{*}}$ and Almustapha A. Aliyu ${ }^{\mathrm{c}}$
}

\author{
${ }^{\mathrm{a}}$ Ministry of Finance Birnin Kebbi, Nigeria
}

${ }^{b}$ Department of Accounting, Federal Polytechnic Birnin Kebbi, Nigeria

${ }^{c}$ Department of Accounting, University of Sokoto, Nigeria \begin{abstract}
A B S T R A C T
This paper discusses Islamic financial reporting system as practiced in many Islamic states for economic development. The issue of Islamic accounting among scholars provided evidence of economic benefits among the countries that have Islamic financial institutions (IFIs). The IFIs have been reported to be the fastest-growing sector in the world with a greater contribution of the global total bank assets. Although the Muslim population in Nigeria is large, the contribution or participation of Muslim towards IFIs is low compared to other countries like Bahrain, Saudi Arabia, Pakistan, and Syria. Furthermore, the accounting reporting in Nigeria is based on the International Financial Reporting Standards (IFRS) for all listed firms in Nigeria, which includes IFIs, even though, IFIs apply dual reporting. Therefore, the need for the mandatory adoption of Accounting and Auditing Organization for Islamic Financial Institutions (AAOIFI) standards is significant in Nigerian for IFIs to function better. Several countries have made it mandatory for IFIs to adopt AAOIFI instead of IFRS. The need for IFIs firms to report on their accounting system as an alternative to the conventional, will not only enhance transparency, improve reporting disclosures, greater Muslim investors, but will also improve Nigerian stock market. Policy makers, governments, and the regulator should make it mandatory for all IFIs to adopt AAOIFI for financial reporting.
\end{abstract}

\section{Introduction}

This paper is to determine the impact of Islamic financial reporting for economic development of Nigeria with the aim to provide the significance of the Islamic accounting in Nigeria. The need for accounting can be traced back to many decades which has been attributed to the ancient civilisation. The ancient Mesopotamia were the earlier people who developed accounting, and that has been closely associated with writing developments, money, counting as well as a system of auditing dated in Egyptians and Babylonians periods. The modern accounting system adopted today could be traced to Luca Pacioli, who was the father of today's economics (Trokic, 2015). The Islamic accounting researchers reported an assumption that conventional method of accounting that has been adopted from Western philosophy may not be comparable with the Muslim values and beliefs (Sivakumar, 2014).

* Corresponding author. Tel: +08035032479

E-mail address: yusufalkali68@yahoo.com (M. Y. Alkali) 
Subsequently, development and emergency of Islamic financial system, Islamic economics, and its institutions, brought about the need for Islamic accounting.

The idea of Islamic accounting has not been new in Islam, due to historical evidence from the period of second Caliph, Umar, in the Islamic State (Trokic, 2015). Furthermore, several verses of the Quran made mentioned the basis of Islamic accounting development and how to be implemented in society (Trokic, 2015).The word Islamic accounting, is a process of measuring, identifying, and communicating economic as well as information that is relevant, encouraged by the Islamic ethics and world view, and have complied with the Sharia law, in order to allow informed judgements and decision by the expected and potential user of information so that social welfare will be enhanced and to seek the blessing of Allah (Mardatillah) (Abdul Rahman, 2010).

According to Napier (2009), Islamic accounting is a convenient way to group mutually agreed practices and ideas of accounting across space and time based on Shari'ah laws. Islamic Accounting is a comprehensive body of concepts and methods that are based on the Shari'ah laws (Islamic laws) (Haniffa \& Hudaib, 2010). Furthermore, Haniffa and Hudaib (2002) concluded that Islamic accounting as a system that seeks to provide socio-economic fairness that has procedures, objective measurements, reporting and control by the Islamic laws and Sharia. The Islamic accounting standards improve confidence on investments and investors among Muslim community with an increase in Zakat collections (Sarea, 2013), and become an important tool that could meet different needs of Islamic Financial Institutions(IFIs) (Sarea \& Mohd Hanefah, 2013).

The different product offered by the IFIs that are in compliance with Islamic Shari' ah may have differed with the conventional banking system. Therefore, development of Islamic financial reporting accounting standards become a significant issue (Vinnicombe, 2010). Also, Sarea and Hanefah (2013) concluded that, the need to fill the gap (differences) between Islamic and conventional reporting require Islamic accounting reporting. The need for corresponding Islamic financial industry as an alternative to conventional standard become imperative for the survival of IFIs, due to the different activities and nature of the banks (Ibrahim \& Shahul, 2007). Thus, Accounting and Auditing Organisation for Islamic Financial Institutions (AAOIFI) standards focus on institutions that provide Islamic financial services was formed.

The report of Pricewaterhouse Coopers (2010), Islamic finance products that are Shari'ah compliant have grown rapidly for the past five years with the increasing significance element of the global economy. The estimated total assets worldwide in 2005 is more than USD250 billion with an estimated fifteen (15\%) percent growth annually (El Qorchi, 2005). The Islamic financial industry has a prediction of growing to about UDS5 trillion in 2016 from USD1 trillion in 2012 period if the annual growth of 25\% continues(News Agency Bahrain, 2012). The assets growth of the IFIs in Malaysia, Saudi Arabia, Pakistan and Syria is greater than the growth of conventional banks. Even in United States of America (USA) small and big investors are gradually dipping into Islamic financing sector that has grown in assets to about USD1.6 trillion all over the world for the past three decades. As a result of the benefits of the Islamic Shari'ah complaints, in 2014 Luxembourg (USA) issued USD254 million, that was over five-year Islamic bond called Sukuk. Sukuk is much similar to traditional bonds, and delivering payments until maturity to investors (Farahani \& Mohammad Hossein, 2012). Also, Hong Kong in the year 2014 sold its Islamic debt by raising USD1 billion in the market. However, the sector has one major problem facing IFIs which lies in the financial reporting preparation using different accounting standards that could result in the issue of reliability, comparability and compliance level's measurement (Sarea \& Hanefah, 2013). The implementation and understanding of the basic accounting standards principles for (IFIs) have become progressively significant among researchers around the world (Sarea, 2012). Presently, IFIs are reported to be the fastest growing sector both locally and globally (Sarea, 2012).

Despite the importance and growth of the Islamic accounting standards for the IFIs, investment opportunity from Muslims investors, the issue of compliance with standards have not been made 
mandatory among IFIs in Nigeria. The Nigerian government has not issued any directive about the compliance with the AAOIFI like IFRS. Although, in February 2015, the Nigerian government formed Islamic Advisory Board for IFIs to oversee the affairs of Islamic banks. But, the AAOIFI reporting standards have been guidelines for IFIs, which reflect the characteristics of the uniqueness of the IFIs and yet there are no mandatory requirements for adoption of the AAOIFI standard. Prior research presented evidence on the need for adopting AAOIFI for IFIs in countries that use Islamic banks or financial institutions (see, Sarea \& Hanefah, 2013), and also, to answer inequality question between Islamic reporting with conventional standards (Murniati Ruslan, 2013).

The expected growth of Islamic finance had excited many, as that will revive Muslims and Islam in the era where they are seen as a threat to the world due to the attitudes of the few (Omar \& Mehboo, 2016). The growth of Islamic accounting has been rapid in recent decades. The investment in Islamic finance products has been increased by an improved desire of complying with Islamic law for Muslim to invest (Schoon, 2009). Recently, Islamic Development Bank offers to provide loan for development and investment in Nigeria, with an existing USD98 million for the Adamawa, Kaduna, Kwara, Gombe, Niger, Nassarwa, Osun and Yobe for the Bilingual Education program (Olalekan, 2016). The benefits of the standard made Sarea and Hanefah (2013) to suggest the implementation of the AAOIFI standards as an important need for IFIs. Several literature reported some countries mandatory adoption of AAOIFI because of its benefits(see, Ibrahim \& Shahul, 2007).

This paper is divided into seven sections. Section two is the Nigerian accounting reporting environment. Next section three the Islamic financial institutions. Followed by section four the concepts of Islamic financial products. Section five, the Accounting Auditing Organisation for Islamic Financial Institutions (AAOIFI) Standards. Next section six, the literature on AAOIFI. Lastly, section seven the conclusion of the study.

\section{Nigerian Accounting Reporting Environment}

The history of Nigerian accounting reporting can be traced back to the of colonisation of Nigeria by the British people. The Nigerian accountants were mostly trained in British before the independence and after the independence of the country. The first accounting body formed in Nigeria was the Institute of Chartered Accountants of Nigeria (ICAN) in the year 1965 by the act of parliament. The ICAN is a firm that initiated accounting standard reporting organization for its members known as Nigerian Accounting Standards Board (NASB) in the year 1982. In the year 1992, NASB became a government agency under the Federal Ministry of Commerce. Thus, in the year 2003 NASB Act was formed to provide the legal framework for accounting standard settings. After that several regulations have been provided for accounting reporting among listed Nigeria firms.

These regulations and rules governing financial reporting in Nigeria namely; (i) Financial Reporting Council Act of 2011 (formerly known as Nigerian Accounting Standards Board (NASB) 1982 become Act in 2003); (ii) NDIC Act 1988; (iii) Central Bank of Nigeria Act 2004; (iv) Company and Allied Matter Act (CAMA) 1990; and (v) Nigerian Stock Exchange (NSE) of 1960. Even though this regulation has been in existence for over two decades yet the accounting reporting is being regarded as weak by the World Bank. Nigerian accounting reporting was pioneered by the British system (IAS) of an accounting system which has frequently been updated, while SAS has not been updated leaving so many gaps of not having relevant accounting information. In the year 2010, the report of the World Bank and Committee on the Road Map to the adoption of IFRS recommended the adoption of IFRS. In the year 2011, the Nigerian government implement the report and change the re-name NASB to the Financial Reporting Council (FRC) in the year 2011. The FRC in 2011 mandated all listed Nigerian firms to adopt IFRS from January 1, 2012. Therefore, all companies that have listed in the Nigerian stock market have commenced, the adoption of IFRS.

The accounting reporting in Nigeria has a close link and approach with the IAS and has a small link to auditing and accounting practice of UK (Mohammed \& Lode, 2012). The accounting system adopted by the regulators and professionals in Nigeria is a private sector driven practices and concepts from UK 
and US. These concepts and principles adopted by the professionals namely; double entry method, reporting in financial statement especially the balance sheet are private sector activities. There was an application of British system of accounting practice by the professionals in Nigeria without modification needed in practice (Jageti \& Nwadike, 2011).

The first accounting standards released by NASB appeared in 1984 as SAS 1 disclosure of accounting policies, SAS 2 for information to be provided in financial statement and SAS3 accounting for property, plant, and equipment. From the increasing number of businesses in the country and demand for more local regulation, the NASB issues 32 SAS from 1986 to 2011 for firms operating in Nigeria. These standards are for regulations and financial reporting settings (NASB, 2005). The requirements of the Nigerian accounting standards are similar to IAS standards. The advantage of implementing IAS is to reduce training expenses in the accounting profession as most of the professionals had their trainings from UK (ICAN, 2000). At the same time businesses operating in the country were from the UK and USA (e.g. Shell, Chevron, and Mobil oil companies).

Nigerian Government has issued International Financial Reporting Standards (IFRS) for all listed firms in Nigeria from the year 2012. The adoption of IFRS in Nigeria is as a result of global pressures from investors and international community fo the harmonisation of financial reporting (Mohammed \& Lode, 2015). Firms that have been issuing Islamic financial products are complying with the both IFRS and AAOIFI in Nigeria. The significance of using IFRS for IFIs is to ease international and Islamic investors to understand, compare and allow a high level of transparency for investment decisions (Pricewaterhouse Coopers, 2010). Currently, IFIs in Nigeria have commenced operations with some conventional banks providing financial product services.

\section{Islamic Financial Institutions in Nigeria}

Nigerian banking sector until recently proposed the Islamic financial product or non-interest banks in banking and other non-banking financial institutions. The financial product was introduced in some of the banks because of the significance of the products among the Muslim population in the country. The majority of Muslims have been financially excluded from the conventional financial products particularly, the fear of interest which Muslims believe is prohibited by Islamic law. Noting that the number of Muslims in the country are large but financially excluded from the traditional service would like to participate in the Islamic or non-interest banking. Also, the demand by banks, global participations, and other financial institutions desire to have Islamic non-interest banking products and services become important to the Nigerian economy. Given the request, the Central Bank of Nigeria (CBN) introduced regulation, guideline, and supervision to the institutions wishing to provide IFIs.

Several regulations and guidelines were introduced for the non-interest banking system that has not been restricted to Islamic banking system, but for any other system that allows non-interest financial services. The Banks and Other Financial Institutions Act (BOFIA) was amended to include the contextual definitions that include other non-interest financial services. In the definition of IFIs, the $\mathrm{CBN}$, classified IFIs into eight (8) categories as, (i) Islamic bank that are full-fledged or subsidiary of conventional bank, (ii) Islamic merchant bank full-fledged or subsidiary of merchant bank, (iii) Islamic microfinance bank full-fledged, (iv) Conventional of Islamic bank branch, (v) Islamic branch, subsidiary of non-bank financial institutions, (vi) banks that are for development and regulated by CBN with Islamic financial services (vii) primary mortgage offering IFSs licensed by the CBN either fullfledged or subsidiary, (viii) licences financial firms governed by CBN to finance financial services, either subsidiary or full-fledged.

The accounting reporting requirements of IFIs in Nigeria include CBN Act 2007, IFRS, AAOIFI, Company and Allied Matter Act (CAMA) 2004, BOFIA 2004, a framework for The Regulations and Supervision of Institutions that are Offering Non-Interest Financial Services in Nigeria 2010 and relevant CBN circulars. These regulations, are provided to the financial institutions that offered noninterest financial services. The first full-fledged non-interest banking financial institution to start 
operation in Nigeria was the JAIZ Bank Plc. Secondly is the LOTUS Capital (Halal Investment) that provide non-interest financial services.

Although, several conventional banks have been offering some of the Islamic financial products before the establishment of Jazz and Lotus capital. For instance, Stanbic Ibtc bank offered non-interest banking accounting known as "The Imaan Transact Plus Account from Stanbic IBTC Bank is a non-interest and non-profit." The bank refers to the account as Islamic product because the system does not allow charging of interest with is in compliance with the Islamic law. Also, the account will not be used for any trade and other activities that are contrary to Islamic principles, such as gambling, alcohol purchase, and many others. However, former Habib Bank plc introduced non-interest banking window that offers limited financial Sharia product, but unfortunately, do not have much significant progress or success.

The CBN provided a model for non-interest financial institutions using specialized banks that include the non-interest financial institution, and Microfinance Banks, Development Banks, Primary Mortgage. The non-interest financial institutions are divided into Islamic financial institutions and Other NonInterest Financial institutions

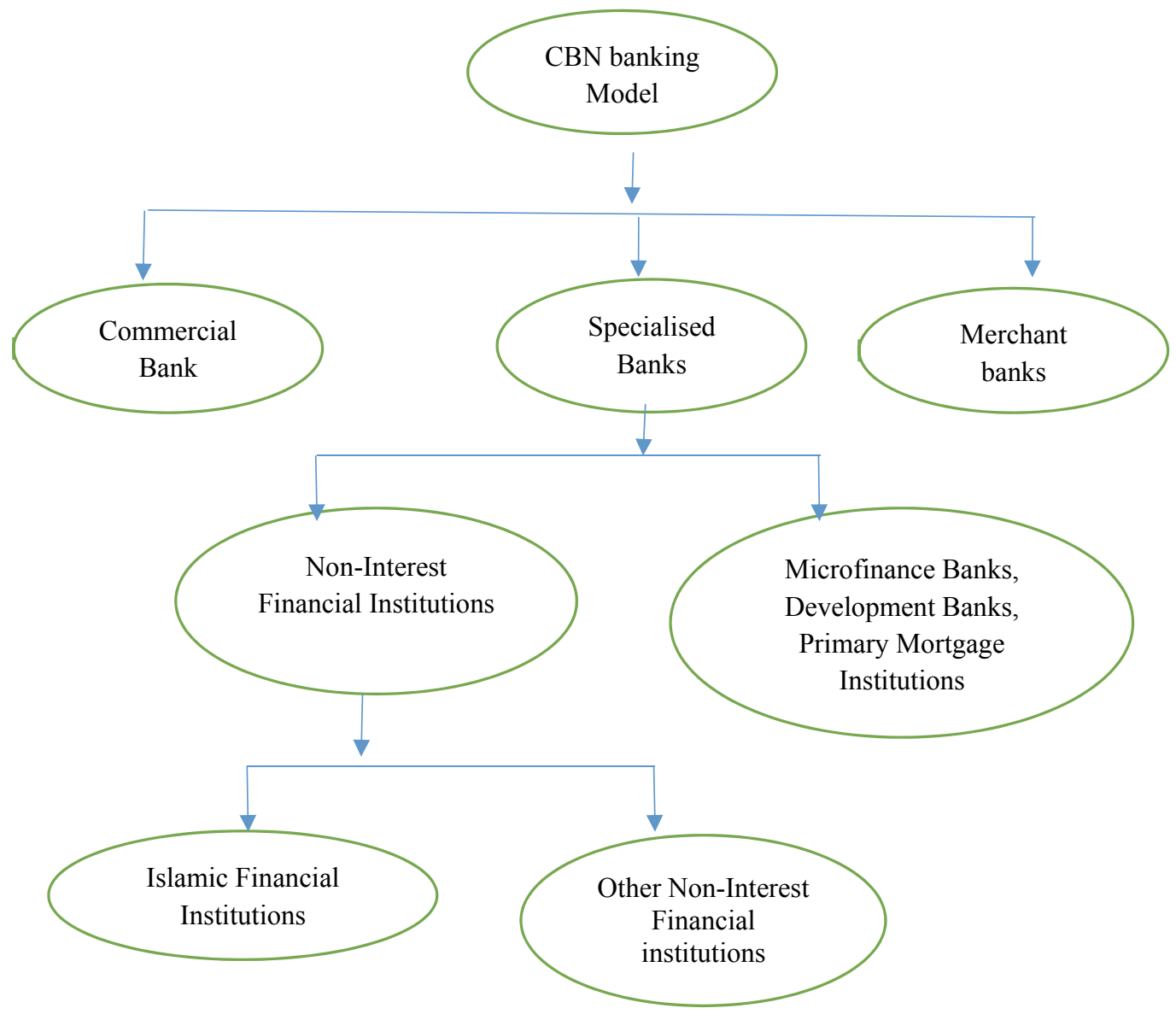

Fig. 1. Model for Islamic financial institutions (CBN, 2015)

\section{The Concepts of Islamic Financial Products}

The development of Islamic banking and finance can be traced back in the period of 1977-78 in Pakistan that eliminated interest in compliance with Islamic Shari'ah among Islamic banks in the country. Moin (2008) reported that, as a result of financial system amendments which allow issuance of interest-free products of corporate finance, encouragements of an ordinance to permit the formation of Mudaraba 
firms and floatation of Mudaraba Certificate establishment of Islamic Banking Departments in Pakistan, provide formation of Islamic banking and finance in Pakistan. The Islamic financial institutions have developed many concepts based on Islamic products to meet the needs of customers as well as to provide alternatives Shari'ah complaints products that are widely obtainable in conventional options.

Faleel (2012) described Islamic financial products based on Islamic law(Shari'ah) to be based on types of contact that are unique. He further stated Islamic financial products are Shari'ah compliant that are productive economic activities within the Islamic principles. He described these products as, (i) they should not create debt, (ii) no payment of interest, (iii)must agree on sharing of risk and responsibility between the parties involved.

These Islamic financial products used contract are as follows.

4.1 Contract partnership: This type of partnership allows for two or more persons to join for business by sharing risk and return. They are classified as, (i) Mudaraba, and Musharaka

4.2 Contracts of exchange: This contract refers to sales contracts which allow for the commodity transfer for another commodity for money, or it could be a transfer of money for money. These are further divided into, (i) Murabaha, (ii) Salam, and (iii) Istisna

4.3 Contracts for Safety and Security: This system is mostly used in Islamic banks to assist business, and individual keep their funds safe, (i) Wadia, (ii) Hiwala, (iii) Kafala, and (iv) Rahn

One of the important concepts in Islamic finance is the Sukuk. The concept of Sukuk refers to Islamic securities or bonds of equal value that represent shares that are undivided in both ownerships of services, tangible assets, and usufructs, assets of actual exceptional investment or particular projects (AAOIFI, 2012). Sukuk applied to capital market related to the procedure of securitisation which defined in general term as Islamic bond (Omar \& Mehboo, 2016).

\section{Accounting and Auditing Organisation for Islamic Financial Institutions(IFIs) Standards}

The need to develop standards on accounting that are based on Islamic financial reporting guidelines become a significant issue in the Muslim world (Vinnicombe, 2010). As a result of the need of accounting reporting based on Islamic conventions, in the year 1991, a body known as the Accounting and Auditing Organisation for Islamic Financial Institutions (AAOIFI) was formed. The organisation is a non-profit body, but Islamic international agencies responsible for governance, accounting, auditing, ethics, as well as Shari'a standards for Islamic financial institutions for the IFIs. Ibrahim and Shahul (2007) suggested that IFIs needs an alternative set off an accounting standard that is corresponding to conventional standards that can best be harmonised, but not regulated based on the differences in activities and nature of the financial institutions and Islamic banks. However, Pricewaterhouse Coopers (2010) argued that there no greater differences between conventional and Islamic finance (AAOIFI) are assumed.

Thus, the need for AAOIFI that have been founded on the Shariah standards for Islamic Institutions become a mandatory regulatory requirement for accounting reporting in Bahrain, Pakistan, Oman, Syria and Sudan as necessary. The standards got more recognition in Islamic Development Bank Group (IDBG) institution. Furthermore, AAOIFI reported that countries like Malaysia and Indonesia adopted the standards as Sharia standard for national Shari'ah jurisdiction and guidelines. Also, AAOIFI, have been considered as voluntary Shari'ah standards by domestic guidelines of the majority of Islamic Financial Institutions(IFIs) in countries like Saudi Arabia, Brunei, Qatar, United Arab Emirates. Additionally, other countries that are non-Arab or Islamic states have also adopted AAOIFI Shari'ah standards, voluntarily for IFIs in their countries (e.g., United Kingdom, South Africa, North America and Central Asia). 
The AAOIFI have two accounting standards requirements referred as, (i) Shari'ah Standards, and (ii) Accounting, Auditing, and Governance Standards and Codes of Ethics. These two standards Sharia and accounting standards are being adopted based on the national Shari'ah guidelines within the jurisdiction of some countries such as Indonesia and Malaysia. Also, the standards have been made mandatory requirements in regulations from other countries like Bahrain, Pakistan, Oman, Syria and Sudan. Also, Islamic Development Bank Group, which is a multilateral institution have also adopted the two standards. Furthermore, other jurisdictions have used the standards on a voluntary basis as internal guidelines in leading Islamic financial institutions (for instance, Brunei, France, Dubai international financial center, Jordan, Kuwait, Saudi Arabia, UAE, even in Africa, North America, Central Asia). However, the financial reporting published in UK IFIs are by either IFRS or UK standards (Pricewaterhouse Coopers, 2010). Nevertheless, the Auditing, Governance, and Ethics Standards under AAOIFI have not been part of mandatory regulatory requirements of IFIs. In its place, these standards are voluntary requirements only for the major Islamic financial jurisdiction of the top Islamic financial institutions.

In Britain, legislation requires all companies to prepare their financial statements by either IFRS as required by either EU or UK GAAP. There are no clear accounting requirements for Islamic finance or the institutions which follow Shari'ah principles. Nonetheless, some UK-based Islamic banks can meet their reporting obligations principally using IFRS. The standards provided different requirements for disclosures that have not been captured by the IFRS. These disclosures are only applicable to Sharia compliance reporting. For instance, the standard requirement of accounting treatment for Zakat under AAOIFI FAS 9(Financial Accounting Standards No.9) are based on the AAOIFI as it is not found in conventional standards. The purpose of the standard is for the standardisation of measurements, recognition, and disclosures in financial reporting of Zakat (Sarea, 2013).

At the end of the year 2015, the Islamic banking assets were are focused within six core markets of Indonesia, Qatar, Malaysia, Saudi Arabia, Turkey, and UAE are expected to have USD1.8 trillion by 2019. Data from Islamic finance.com have shown that Alrajhi as the world's biggest Islamic Bank provided assets of US\$62 billion (2015) while the National Commercial Bank of Saudi-based could likely to be greater than Alrajhi Bank once they become fully-fledged. Fig. 2 shown the contributions of countries

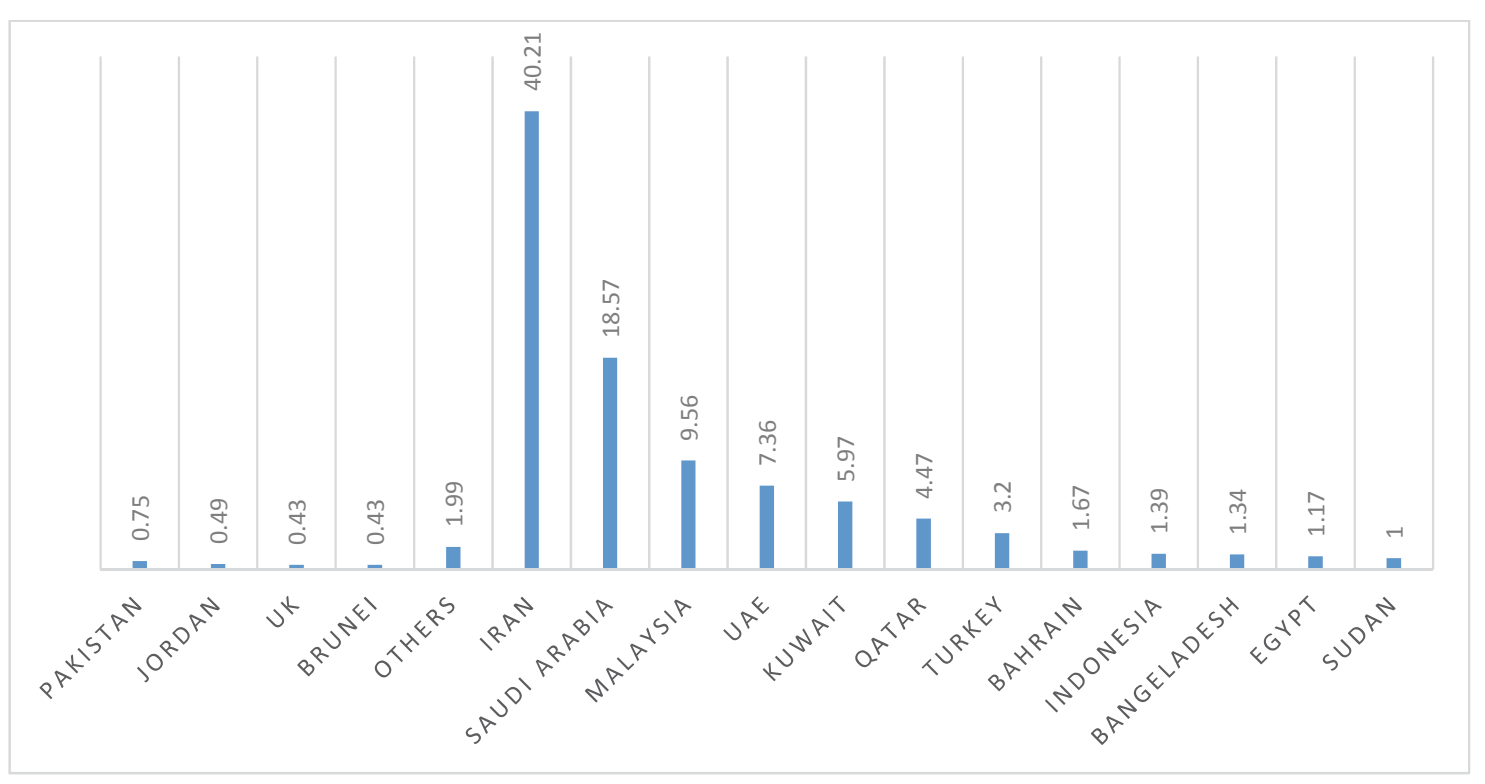

Fig. 2. Source: IFSB Stability Report, 2015 
The main differences between AAOIFI and IFRS are that the first is based on Islamic laws or Sharia laws, and the latter is based on the regulations adopted by many countries. Some of the differences have been classified based on adoption and characteristics in Table1.

Table 1

Differences between AAOIFI and IFRS

\begin{tabular}{|c|c|c|}
\hline & AAOIFI & IFRS \\
\hline Adoption & $\begin{array}{l}\text { To Islamic banking and finance not covered by } \\
\text { IFRS/IASB }\end{array}$ & $\begin{array}{l}\text { Based on all economic and social } \\
\text { activities including Islamic finance } \\
\text { industry }\end{array}$ \\
\hline $\begin{array}{l}\text { Standard } \\
\text { requirements }\end{array}$ & Based on the Islamic finance practice & Generic, not industry specific accounting \\
\hline Standard types & $\begin{array}{l}\text { Accounting, Shari'ah, Auditing, Ethics and } \\
\text { Governance }\end{array}$ & Accounting standard \\
\hline Reasons for issue & IFRS do not capture Islamic IFIs & Need to harmonised IFRS globally \\
\hline Compliance & Based on Shari'ah & Non-sharia compliance \\
\hline Specific & $\begin{array}{l}\text { FAS 1(general presentation \& disclosure in } \\
\text { financial statement of IFIs) covers } \\
\text { IAS1(presentation), } 7 \text { (cash flows, } 18 \text { (Revenue) }\end{array}$ & Different reporting under IFRS \\
\hline Specific & $\begin{array}{l}\text { FAS2(Murabaha, \& Muradaba to the purchase } \\
\text { order), FAS 7(Salam and parallel salam) }\end{array}$ & Not in IFRS \\
\hline \multirow[t]{4}{*}{$\begin{array}{l}\text { Sources of funds: } \\
\text { Investment account }\end{array}$} & $\begin{array}{l}\text { Unrestricted investment account funds from } \\
\text { customers }\end{array}$ & Shareholdings \\
\hline & Mudaraba investments profit sharing agreement & Dividend \\
\hline & $\begin{array}{l}\text { Mudaraba loss arising from investment bank not } \\
\text { reliable }\end{array}$ & Bank reliable for loss \\
\hline & $\begin{array}{l}\text { Statement of Unrestricted investment to presented } \\
\text { in statement of financial position different item } \\
\text { between equity of owners and liabilities }\end{array}$ & $\begin{array}{l}\text { To be submitted as liabilities along with } \\
\text { the deposits }\end{array}$ \\
\hline Leasing (Ijarah) & $\begin{array}{l}\text { As a major financing mechanism } \\
\text { Treated similarly to operating lease }\end{array}$ & Dealt with as financing lease only \\
\hline
\end{tabular}

\section{Literature of AAOIFI}

Studies on the AAOIFI has been conducted in various countries as a result of the growth of Islamic banking and finance in recent decades. The significance of the introduction of Islamic financial products into banking sectors and the need for inclusion of AAOIFI as part of reporting requirements to encourage Muslim investors to participate in Islamic banking and finance brought about studies on Islamic accounting. These studies reported compliance with AAOIFI standards by some countries. For instance, the study of Sarea and Hanifah (2013a), and Sarea (2012) indicated full convergence with AAOIFI accounting standards among Islamic banks of Bahrain. But, Vinnicombe (2010) concluded a very high compliance in respect to the governance standards of the supervisory board and reporting of Islamic Murabaha contract in Islamic banks. However, the study presented lower compliance concerning Zakat and Mudaraba among Bahrain IFIs. Also, Ullah (2013) reported low compliance with the AAOIFI standards among Islamic Banks listed in Bangladesh.

Mohammed et al. (2015) reported the need for convergence between AAAOIFI and the International Accounting Standard Board (IASB) framework, as that will assist collaboration of guidelines of IFIs to be accepted globally. In contrast, Sarea (2013) argued that adopting AAOIFI for IFIs are the better choice for Muslim investor's confidence and increasing investment opportunity among IFIs. Furthermore, (Ibrahim \& Shahul, 2007) agreed on the need for a similar alternative system of financial reporting with the IFRS because of the activities and nature of IFIs differences.

Among the standards compliance, other new accounting reporting standards on Sukuk have not be complied by IFIs. There is a significant increase in Sukuk for the last few years as a means of raising finances by the government through sovereign issues and as a way for firms in getting funds as a result of corporate Sukuk (Khalil Ahmed, 2011). Naim (2013) provided evidence of non-compliance with 
Sukuk as new reporting standard due to the strong criticism towards the end of 2007 by Shaykh that, the majority (85\%) of Sukuk issuance deviate from Shari'ah teaching. Wilson (2006) reported vehicles that are for special purpose are the prerequisite for the management and successful issuance of Sukuk. The pricing benchmarks base on the GDP could result in higher stability of payments for debt that are sovereign in Saudi Arabia, however, countries like Malaysia could not be possible.

Studies on modaraba based on Islamic reporting have been conducted in various countries. The mudharaba offers equity financing in Islamic financial information requiring sharing of profit and loss (PLS). Nidaussalam (2016) reported that once profit is high under mudharib, investors will receive more benefit. However, Muda, Ismail, and Shahimi (2007) could not found any significant increase on Mudharib arrangements on the deposits structures in Islamic banks. But, reported a substantial increase in the value of Islamic banks based on allocated in Securities Investment (FIM) under Mudharaba arrangement.

\section{Conclusion}

The Muslims population in Nigeria highly significant to improve the economic development of the country. The majority of the population of Muslims have been financially excluded from the conventional banking system. Those that invested in the conventional banks find it difficult to accept interest generated from the savings or businesses that are not in compliance with Shari'ah legal system. The Islamic system has been a convenient way for Muslims to invest in a business that complies with the Shari'ah. In several Islamic countries, investments in the IFIs have been massive and attracts much attention to other countries like UK, US, South Africa and Canada. The rapid growth of the sector has improved many economies in Asia, Africa and particularly its contributions to the Nigerian economic development through IDB. Although, the significance of the sectors has been witnessed in Nigeria, however, the number of IFIs are limited in the economy. Given that, the large population of Muslims in Nigeria, investments in the Islamic financial sector would bring in more investors to participate in the Nigerian economy. Considering the Northern part of Nigeria were more than $60 \%$ of the population are Muslims, and mostly Small and Medium enterprises could take part in the building of the Nigerian economy through IFIs. Therefore, policy makers, government, and Muslim community should be involved in IFIs, particularly, mandating IFIs to adopt AAOIFI for financial reporting. Further studies could consider the effect of the IFIs on the Muslims participation and contributions of IFIs, for the reduction of poverty and economic development of Nigeria.

\section{References}

Abdul Rahman, A. R. (2010). An Introduction to Islamic Accounting Theory and Practice.

El Qorchi, M. (2005). Islamic finance gears up. Finance and Development, 42(4), 46-49.

Faleel, J. (2012). Islamic financial products based on Sharia-compliant contracts.

Farahani, G., \& Mohammad Hossein, S. (2012). Analysis of Islamic Bank's Financing and Economic Growth: Case Study Iran and Indonesia. Journal of Economic Cooperation and Development, 33(4), $1-24$.

Haniffa, R., \& Hudaib, M. (2002). A theoretical framework for the development of the Islamic perspective of accounting. Accounting, Commerce and Finance: The Islamic Perspective Journal, $6(1 \& 2), 1-72$.

Haniffa, R., \& Hudaib, M. (2010). The two Ws of Islamic accounting research. Journal of Islamic Accounting and Business Research, 1(1), 5-9. http://doi.org/10.1108/17590811011033370

Ibrahim, M., \& Shahul, H. (2007). IFRS vs AAOIFI: The Clash of Standards. Munich Personal RePEc Archive, (November), 1-10. http://doi.org/10.5897/JAERD12.088

Khalil Ahmed. (2011). Sukuk: Definition, Structure and Accounting Issues. Munich Personal RePEc Archive, (33675).

Mohammed, N. F., Fahmi, F. M., \& Ahmad, A. E. (2015). The Influence of AAOIFI Accounting Standards in Reporting Islamic Financial Institutions in Malaysia. Procedia Economics and Finance, 31, 418-424. http://doi.org/10.1016/S2212-5671(15)01216-2 
Mohammed, Y. A., \& Lode, N. A. (2012). Efforts and challenges in adopting International Financial Reporting Standards (IFRS) in Nigeria. Journal of Business Management and Accounting, 2(2), 81100.

Mohammed, Y. A., \& Lode, N. A. (2015). The Value relevance of accounting disclosures among Nigerian financial institutions after the IFRS Adoption. Mediterranean Journal of Social Sciences, 6(1), 409-418. http://doi.org/10.5901/mjss.2015.v6n1p409

Moin, M. S. (2008). performance of islamic banking and conventional banking in pakistan. university of scovde. Retrieved from http://www.diva-portal.org/smash/get/diva2:113713/FULLTEXT01

Muda, R. B., Ismail, A. G., \& Shahimi, S. (2007). Profit-Loss Sharing and Economic Value Added in Islamic Banking Model. Complexity, (October 2005), 1-106.

Murniati Ruslan. (2013). Sistem Mudharabah dan apikasinya pada Bank Syariah Mandiri Cabang Palu. Ilmiah, 1(2), 14.

Naim, A. M. (2013). The effects of new AAOIFI standards on Sukuk in choosing the most authentic Islamic principles. Journal of Islamic Accounting and Business Research, 4(1), 77-93.

Napier, C. (2009). Defining Islamic accounting. Accounting History, 14(1/2), 121-144.

NewsAgencyBahrain. (2016). Islamic Finance Set To Reach US\$5 Trillion By 2016.

Nidaussalam, M. (2016). Mudaraba as a Model of Islamic Finance. Shirkah Journal of Economics and Business, 1(1), 73-92.

Olalekan, A. (2016). Islamic bank's offer to Nigeria excites Buhari. Punch Newspaper, p. 23.

Omar, J., \& Mehboo, ul H. (2016). A comparison of Islamic and Capitalist Conception of Economic Justice. In Essential Perspectives in Islamic Econimics and Finance (p. 85).

Pricewaterhouse Coopers. Open to comparison: Islamic Finance and IFRS (2010).

Sarea, A. M. (2012). The Level of Compliance with AAOIFI Accounting Standards : Evidence from Bahrain. International Management Review, 8(2), 27-32.

Sarea, A. M. (2013). Accounting Treatment of Zakah: Additional Evidence from AAOIFI*. Journal of Islamic Banking and Finance, 1(1), 23-28. Retrieved from http://aripd.org/journals/jibf/Vol_1_No_1_December_2013/3.pdf

Sarea, A. M., \& Hanefah, M. M. (2013a). A Adoption of AAOIFI accounting standards by Islamic banks of Bahrain. Journal of Financial Reporting and Accounting, 11(2), 131-142.

Sarea, A. M., \& Hanefah, M. M. (2013b). The Need of Accounting Standards for Islamic Financial Institutions: Evidence from AAOIFI. Journal of Islamic Accounting and Business Research, 4(1), 64-76. http://doi.org/10.1108/17590811311314294

Sarea, A. M., \& Mohd Hanefah, H. M. (2013). The Need of Accounting Standards for Islamic Financial Institutions. International Management Review, 9(2), 50-59.

Schoon, N. (2009). Islamic Banking and Finance. Judaism, 203.

Sivakumar, V. (2014). Conventional" accounting vs "Islamic" accounting: the debate revisited. Journal of Islamic Accounting and Business Research, 5(2), 126-141.

Trokic, A. (2015). Islamic Accounting; History, Development and Prospects. European Journal of Islamic Finance, 3(12), 1-6.

Ullah, M. H. (2013). Compliance of AAOIFI Guidelines in General Presentation and Disclosure in the Financial Statements of Islamic Banks in Bangladesh. International Journal of Social Science Research, 1(2), 111-123. http://doi.org/10.14239/IJSSR.2013.01205

Vinnicombe, T. (2010). AAOIFI reporting standards: Measuring compliance. Advances in Accounting, 26(1), 55-65.

Wilson, R. (2006). Innovation in the structuring of Islamic sukuk securities. 2nd Banking and Finance International Conference. Beirut: Lebanese American University, 24(3), 170-181.

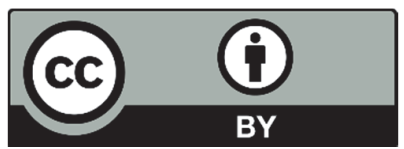

(C) 2017 by the authors; licensee Growing Science, Canada. This is an open access article distributed under the terms and conditions of the Creative Commons Attribution (CC-BY) license (http://creativecommons.org/licenses/by/4.0/). 